\title{
EFFICIENCY AND PRODUCTIVITY PERFORMANCE OF THE NATIONAL PRIVATE BANKS IN INDONESIA
}

\author{
Mohd. Azmi Omar \\ M. Shabri Abd. Majid \\ Ronald Rulindo
}

This study investigates the efficiency and productivity performance of the national private banks in Indonesia during the period of 2002-2004. The data consist of 21 national private banks including two Islamic banks. Productivity is measured by the Malmquist Index using Data Envelopment Analysis (DEA) technique. Overall, the result shows that the Total Factor Production (TFP) Index of the national private banks has considerably increased for the whole industry, in which technical change is found to be a more important source of productivity growth to the Indonesian Banking Industry compared to efficiency change. Furthermore, the result also shows that the efficiency of two Islamic banks is above the average efficiency of the national private banks.

Keywords: bank efficiency; data envelopment analysis (DEA); Islamic versus conventional banks; Malmquist index 
Gadjah Mada International Journal of Business, January - April 2007, Vol. 9, No. 1

\section{Introduction}

The efficiency of financial service industry has long been a focus of banking research in the last few decades. The amount of attention that banking efficiency research has received is understandable. Their findings have obvious implications for bank management who seeks to improve efficiency and productivity performance, and for policy makers who are concerned about banking competition and bank safety and soundness (Kwan 2003). Efficiency would also imply improved profitability, greater amount of funds channelled in, better prices and service quality for customers and greater safety in terms of improved capital buffer in absorbing risk (Berger et al. 1993). Hence, the study of efficiency is important since competition in the financial service industry is tougher than ever in the era of globalization. Therefore, only efficient banks will survive, and efficiency per se is related to productivity and profitability. Motivated by this fact, this study tries to explore the efficiency and productivity performance of 21 national private banks in Indonesia. It also attempts to compare the efficiency and productivity performance between Islamic banks and their conventional counterparts in Indonesia.

To achieve the above outlined objectives, this study uses a nonparametric approach of Data Envelopment Analysis (DEA) together with Malmquist Index. This approach isolates the contributions of technical change, efficiency change, pure and scale changes in Total Factor Productivity (TFP) growth of different national private banks and the Islamic banks in Indonesia.

The rest of this study is organized as follows. Section 2 provides a brief overview of the national private banks in Indonesia. Section 3 reviews relevant literature of the banking efficiency whilst Section 4 discusses the methodology of DEA and Malmquist Index. Section 5 presents the results and analysis, and finally the conclusion is presented in Section 6 .

\section{Brief Overview of the National Private Banks in Indonesia}

In general, banks in Indonesia can be divided into two main categories: (1) commercial banks (Bank Umum) and (2) rural credit banks (Bank Perkreditan Rakyat). Predicated upon the ownership of the banks, commercial banks can be further classified into four types: (1) state-owned banks, which are owned by the government; (2) national private banks, which are owned by private sector; (3) regional development banks, which are possessed by provincial governments; and (4) foreign and joint venture banks, which are jointly owned by foreign and local companies. As for national private banks, some banks have foreign exchange division whilst some others do not.

The number of the national private banks in Indonesia shows a de- 
Omar etal.-Efficiency and Productivity Performance of the NationalPrivate Banks...

creasing trend from 2001 to 2006 . Taking together national private banks and foreign and joint venture banks, the number of the banks were 81 banks in January 2001. However, at the beginning of year 2006, the number of the banks dropped to 71 banks. The main rationale for the reduction in the number of national private banks and foreign and joint venture banks during the period is due to merger and liquidation. Moreover, national private banks' branches over the country kept increasing from only 1,070 in January 2001 to 1,274 at the beginning of year 2006 .

In addition, the amount of demand deposits of the national private banks also increased from only IDR81.3 trillion in 2001 to IDR283.9 trillion in January 2006. The national private banks have shared capital amounting to more than IDR100 billion from 2002 to 2006. The personnel expenses, capital expenditures, and total deposits of the 21 national private banks examined in the study have, on average, amounted to IDR17.12 trillion during the period of 2002-2004. On average, their loans and advances reached IDR7.42 trillion during the same period. Finally, the average of total money and capital market investments of the 21 national private banks during the period of 2002-2004 amounted to IDR8.59 trillion.

\section{Literature Review}

The measurement of bank efficiency is mostly focused on two different approaches: (1) parametric and (2) nonparametric methods. The most commonly used parametric approaches are the Stochastic Frontier Approach (SFA), Distribution Free Approach (DFA), and the Thick Frontier Approach (TFA). Meanwhile, the most commonly used nonparametric approaches are the Data Envelopment analysis (DEA) and the Free Disposable Hull (FDH) (Berger and Humphrey 1997).

This research will apply the nonparametric approach using Data Envelopment Analysis (DEA). DEA is a mathematical programming approach which constructs the frontier of observed input-output ratios by linear programming techniques. It estimates efficiency under the assumption of constant returns to scale and variable returns to scale. DEA assumes that linear substitution is possible between observed input combinations on an isoquant.

DEA with Malmquist Index has extensively been harnessed in exploring the efficiency and productivity performance of financial institutions. Sathye (2002) analyses the change in the productivity of Australian banks during the period of 1995-1999. Based on intermediation approach, his data consisted of annual observation of outputs, i.e., net interest income and noninterest income, and inputs such as interest expenses and non-interest expenses. The study finds that technical efficiency of banks in the panel has declined by 3.1 percent and the TFP has declined by 3.5 percent. For the European and U.S. banking systems, 
Pastor et al. (1997) use a different approach, which is called the Added Value Approach, to selecting the output and input variables. Loans, other productive assets and deposits are selected as outputs whilst non-interest expenses and personal expenses are taken as inputs. The study finds that France, Spain, and Belgium appear to be countries with the most efficient banking systems whereas U.K., U.S., and Germany show the lowest efficiency levels. Selecting different input and output combination for U.S. banking system, Wheelock and Wilson (1999) and Mukherjee et al. (2001) document that for the period of 19841990, banks of all size experienced a reduction in technical efficiency and that, on average, the productivity growth was about 4.5 percent annually.

\section{Methodology}

In exploring the contributions of technical and efficiency changes to the growth of productivity of the private national banks in Indonesia, the generalized output-oriented Malmquist index developed by Fare et al. (1989) is adopted in this study. The Malmquist index is constructed using the Data Envelopment Approach (DEA) and estimated using Coelli's (1996) DEAP version 2.1. Malmquist index is chosen on account of a number of desirable features for this particular study. The DEA does not require input prices or output prices in its construction, which makes the method particularly useful in a situation in which prices are not available publicly or nonexistent. Neither does it require behavioral assumptions, such as cost minimization or profit maximization in the case where the producers' objectives differ, are unknown or unachieved. This is firstly demonstrated by Fare et al. (1989) using the geometric mean formulation of the Malmquist index. Following this, Forsund (1991) derives the decomposition of simple version of the Malmquist productivity index into technical and efficiency changes.

Fare et al.'s (1994b) list several traditional methods to calculate the Malmquist productivity index. But most of them require specification of a function form for technology. Charnes et al. (1978) propose the DEA to construct a best-practice frontier without specifying production technology. Unlike traditional analysis techniques that look for the average path through the middle point of a series of data, the DEA looks directly for a best-practice frontier within the data. Using a nonparametric linear programming technique, the DEA takes into account of all the inputs and outputs as well as differences in technology, capacity, competition, and demographics, and then compares individual with the bestpractice (efficiency) frontier. According to Ali and Seiford (1993), the DEA is a well-established nonparametric efficiency measurement technique, which has been extensively utilized in over 400 studies of efficiency in management sciences during the last decade. 
Omar etal.-Efficiency and Productivity Performance of the NationalPrivate Banks...

Heretofore, the Malmquist productivity index and the DEA have been used in a vast array of studies. These studies include an aggregate comparison of productivity amongst countries (Fare et al. 1994a) as well as various economic sectors such as agriculture by Tauer (1998) and Mao and Koo (1996), airlines by Alam and Sickles (1995), telecommunications industry by Asai and Nemoto (1999) and Calabrese et al. (2001), banking by Tulkens and Malnero (1996), universities by Avkiran (2001), insurance by Cummins et al. (1999) and Diacon et al. (2002).

Following Fare et al. (1989), the Malmquist index of total factor productivity growth is written as follows:

$$
\begin{aligned}
& M_{0}\left(x^{t}, y^{t}, x^{t+1}, y^{t+1}\right)= \\
& \frac{D_{0}{ }^{t+1}\left(x^{t+1}, y^{t+1}\right)}{D_{0}{ }^{t}\left(x^{t}, y^{t}\right)} x \\
& {\left[\left(\frac{D_{0}{ }^{t}\left(x^{t+1}, y^{t+1}\right)}{D_{0}{ }^{t+1}\left(x^{t+1}, y^{t+1}\right)}\right)\left(\frac{D_{0}^{t}\left(x^{t}, y^{t}\right)}{D_{0}{ }^{t+1}\left(x^{t}, y^{t}\right)}\right)\right]^{\frac{1}{2}}}
\end{aligned}
$$

where the notations $D_{0}^{t}\left(x^{t+1}, y^{t+1}\right)$ represents the distance from the period $t+1$ observation to the period $t$ technology. The first ratio on the right hand side of equation (1) measures the change in relative efficiency (i.e., the change in how far observed production is from maximum potential production) between year $t$ and year $t+1$.
The second term inside the brackets (geometric mean of the two ratios) captures the shift in technology (i.e., movements of the frontier function itself) between the two periods evaluated at $x^{t}$ and $x^{t+1}$. Essentially, the change in relative efficiency measures how well the production process converts inputs into outputs (catching up to the frontier) and the later reflects improvement in technology. According to Fare et al. (1994a), improvements in productivity yield Malmquist index values greater than unity. Deterioration in performance over time is associated with Malmquist index less than unity. The same interpretation applies to the values taken by the components of the overall TFP index. Improvements in the efficiency component yield index values greater than one, and are considered to be evidence of catching up (to the frontier). Values of the technical change component greater than one are considered to be evidence of technological progress.

In empirical applications, four distance measures that appear in equation (1) above are calculated for each operator in each pair of adjacent time periods using mathematical programming technique. Assume that there are $k=1, \ldots, K$ firms that produce $m=1, \ldots$, $M$ outputs $y_{k, m}^{t}$ using $n=1, \ldots, N$ inputs $x_{k, n}^{t}$ at each time period $t=1, \ldots, T$. Under the DEA, the reference technology with constant returns to scale(CRS) at each time period $t$ from the data can be defined as: 
Gadjah Mada International Journal of Business, January - April 2007, Vol. 9, No. 1

$$
\begin{aligned}
& \mathrm{G}^{\mathrm{t}}=\left[\left(\mathrm{x}^{\mathrm{t}}, \mathrm{y}^{\mathrm{t}}\right): \mathrm{y}_{\mathrm{m}}^{\mathrm{t}} \leq \sum_{\mathrm{k}=1}^{\mathrm{K}} \mathrm{z}_{\mathrm{k}}^{\mathrm{t}} \mathrm{y}_{\mathrm{k}, \mathrm{m}}^{\mathrm{t}}\right] \\
& \mathrm{m}=1, \ldots, \mathrm{M}, \\
& \sum_{\mathrm{k}=1}^{\mathrm{K}} \mathrm{z}_{\mathrm{k}}^{\mathrm{t}} \mathrm{y}_{\mathrm{k}, \mathrm{n}}^{\mathrm{t}} \leq \mathrm{x}_{\mathrm{n}}^{\mathrm{t}} \quad \mathrm{n}=1, \ldots, \mathrm{N}, \\
& \mathrm{z}_{\mathrm{k}}^{\mathrm{t}} \geq 0 \quad \mathrm{k}=1, \ldots, \mathrm{K},
\end{aligned}
$$

where $z_{k}^{t}$ refers to weight on each specific cross-sectional observation. Following Afriat (1972), the assumption of constant returns to scale may be relaxed to allow variable returns to scales by adding the following restriction:

$$
\sum_{\mathrm{k}=1}^{\mathrm{K}} \mathrm{z}_{\mathrm{k}}^{\mathrm{t}}=1
$$

Following Fare et al. (1994a), this study uses an enhanced decomposition of the Malmquist index by decomposing the efficiency change component calculated relative to the constant returns to scale technology into a pure efficiency component (calculated relative to the VRS technology), and a scale efficiency change component which captures changes in the deviation between the VRS and CRS technology. The subset of pure efficiency change measures the relative ability of operators to convert inputs into outputs whilst scale efficiency measures to what extent the operators can take advantage of returns to scale by altering its size towards optimal scale.

To construct the Malmquist productivity index of firm $k$ ' between $t$ and $t+1$, the following four distance functions are calculated using the DEA approach: $D_{0}^{t}\left(x^{t}, y^{t}\right), D_{0}^{t+1}\left(x^{t}, y^{t}\right), D_{0}^{t}\left(x^{t+1}\right.$, $\left.y^{t+1}\right), D_{0}^{t+1}\left(x^{t+1}, y^{t+1}\right)$. These distance functions are the reciprocals of the output-based Fare et al's (1994b) measure of technical efficiency. Nonparametric programming models utilized to calculate the output-based Fare et al.'s (1994b) measure of technical efficiency for each firm $k^{\prime}=1, \ldots, K$, are expressed as:

$$
\left[\mathrm{D}_{0}^{\mathrm{t}}\left(\mathrm{x}_{\mathrm{k}^{\prime}}^{\mathrm{t}}, \mathrm{y}_{\mathrm{k}^{\prime}}^{\mathrm{t}}\right)\right]^{-1}=\max \lambda^{\prime \mathrm{k}^{\prime}}
$$

subject to

$$
\begin{array}{cc}
2 y^{k^{\prime}} y_{k, \mathrm{~m}}^{t} \leq \sum_{k=1}^{X} z_{k, 1}^{t} y_{k, \mathrm{t}}^{t} & m=1, \ldots, M, \\
\sum_{\mathrm{k}=1}^{\mathrm{K}} \mathrm{z}_{\mathrm{k}}^{\mathrm{t}} \mathrm{x}_{\mathrm{k}, \mathrm{n}}^{\mathrm{t}} \leq \mathrm{x}_{\mathrm{k}, \mathrm{n}}^{\mathrm{t}} & n=1, \ldots, N, \\
\sum_{\mathrm{k}=1}^{\mathrm{K}} \mathrm{z}_{\mathrm{k}}^{\mathrm{t}}=1 & (V R S) \\
z_{k}^{t} \geq 0 & k=1, \ldots, K,
\end{array}
$$

The computation of $D_{0}^{t+1}\left(x^{t+1}, y^{t+1}\right)$ is similar to that of equation (5), where $t+1$ is substituted for $t$. 
Omar etal.-Efficiency and Productivity Performance of the NationalPrivate Banks...

The construction of the Malmquist index also requires the calculation of two mixed-distance functions, computed by comparing observations in one time period with the best practice frontier in another time period. The inverse of the mixed-distance function for observation $k$ 'can be obtained from

$$
\left[D_{0}^{\mathrm{t}}\left(\mathrm{x}_{\mathrm{k}}{ }^{\mathrm{t}+1}, \mathrm{y}_{\mathrm{k}}{ }^{\mathrm{t}+1}\right)\right]^{-1}=\max \lambda^{\prime} \mathrm{k},
$$

subject to

$$
\begin{aligned}
& y^{k} y_{k, \mathrm{M}}^{t+1} \leq \sum_{k=1}^{X} z_{k}^{t} y_{k,+1}^{t} \quad m=1, \ldots M, \\
& \sum_{\mathrm{k}=1}^{\mathrm{K}} \mathrm{z}_{\mathrm{k}}^{\mathrm{t}} \mathrm{x}_{\mathrm{k}, \mathrm{n}}^{\mathrm{t}} \leq \mathrm{x}_{\mathrm{k}^{\prime}, \mathrm{n}}{ }^{\mathrm{t}+1} \quad n=1, \ldots, N, \\
& \sum_{k=1}^{K} z_{k}^{t}=1 \\
& Z_{k}^{t} \geq 0 \quad k=1, ., K
\end{aligned}
$$

To measure changes in scale efficiency, the inverse output distance functions under the VRS technology are also calculated by adding equation (3) into the constraints in equation (5) and equation (7). Technical change is calculated relative to the CRS technology. Scale efficiency change in each time period is constructed as the ratio of the distance function satisfying CRS to the distance function under VRS, whilst the pure efficiency change is defined as the ratio of the own-period distance functions in each period under VRS. With these two distance functions with respect to the VRS technology, the decomposition of Equation (1) becomes:

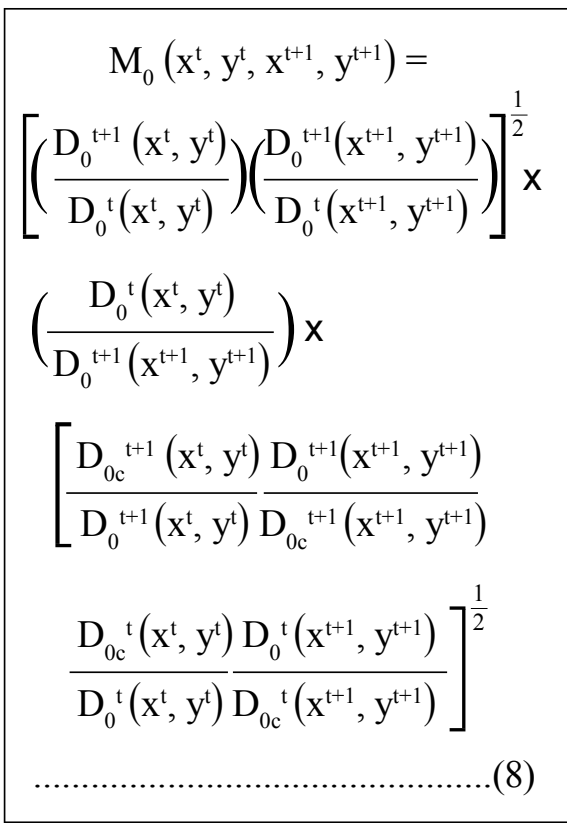

where the first, second, and third terms inside the brackets measure the technical change, pure efficiency change, and scale efficiency change, respectively. It should be noted that when the technology in fact exhibits CRS, the scale change factor equals to one, and it is the same decomposition as equation (1).

\section{Input and Output Selection}

This study explores efficiency and productivity performance of 21 national private banks in Indonesia. These banks include Bank Danamon Indone- 
Gadjah Mada International Journal of Business, January - April 2007, Vol. 9, No. 1

sia, Bank International Indonesia, Bank Pan Indonesia, Bank Century, Bank Central Asia, Bank Permata, Bank Buana Indonesia, Bank LIPPO, Bank Niaga, Bank Bukopin, Bank NISP, Bank Mega, Bank Syariah Mandiri, Bank Ganesha, Bank Artha Graha International, Bank Mayapada International, Bank IFI, Bank Muamalat Indonesia, Bank Bumiputera Indonesia, Bank Ekonomi Raharja, and Bank Mestika Dharma. Of the 21 national private banks chosen in the study, two Islamic banks (Bank Syariah Mandiri and Bank Muamalat Indonesia) are also included in this study's sample. Like other 19 conventional banks owned by private sector, the two Islamic banks included in the study are also owned by private sector. Therefore, the study classifies them as national private banks. During the study period, there are only two fully-pledged Islamic banks existing in Indonesia, which are Bank Syariah Mandiri and Bank Muamalat Indonesia. The latest fully-pledged Islamic bank, Bank Syariah Mega Indonesia which was established in 2004, is excluded from our analysis since the period of the study ranges from 2002 to 2004 .

There has been a matter of long standing debate amongst researchers on the definition and measurement of a bank's inputs and outputs. In defining inputs and outputs, three main approaches have been widely utilized in banking literature: (1) the production approach, (2) the intermediation approach, and (3) the modern approach.
The first two approaches apply traditional microeconomic theory of the firm to banking and differ only in the specification of banking activities. The third approach goes a step further and incorporates some specific activities into the classical theory.

Since the intermediation approach has been extensively used in determining the outputs of banking industry, this study accordingly adopts this approach. Three inputs and outputs are selected to investigate the efficiency of 21 national private banks in Indonesia. The inputs are: (1) total deposits, (2) personnel expenses, and (3) capital expenses. Meanwhile, the outputs embrace: (1) loans and advances, (2) capital market investments, and (3) money market investments.

Table 1 reports the descriptive statistics of inputs and outputs of the 21 national private banks in Indonesia during the study period. On average, loans and advances and total deposits are the most common outputs and inputs in the national private banks, respectively. Interestingly, the number of capital market investment (CMI) of the national private banks is high, but it does not reflect the national private banks as a whole since this figure is only dominated by the CMI of bigsized banks, e.g., Bank Central Asia, Bank Danamon, Bank Permata, etc. Of the 21 national private banks, Bank Central Asia is found to have the highest figures of inputs and outputs. On the other hand, Bank IFI is found to have the lowest inputs and outputs, 
Omar etal.-Efficiency and Productivity Performance of the NationalPrivate Banks...

Table 1. Descriptive Statistics (in Million IDR)

\begin{tabular}{|c|c|c|c|c|c|}
\hline & Mean & Median & Maximum & Minimum & Std Dev \\
\hline \multicolumn{6}{|l|}{ Input: } \\
\hline Personnel Expenses & 246,689 & 107,727 & $1,808,824$ & 7,896 & 371,182 \\
\hline Total Deposit & $16,829,245$ & $11,159,3661$ & $31,996,279$ & 438,556 & $25,183,550$ \\
\hline Capital Expenditures & 39,934 & 26,400 & 718,675 & $-817,724$ & 157,609 \\
\hline \multicolumn{6}{|l|}{ Output: } \\
\hline Loan and Advance & $7,418,297$ & $5,338,108$ & $40,383,971$ & 293,837 & $7,845,935$ \\
\hline Money Market Investment & it $2,369,208$ & 355,004 & $36,849,471$ & 0 & $6,431,144$ \\
\hline Capital Market Investmen & it $6,530,834$ & $1,724,627$ & $57,257,101$ & 49 & $12,045,071$ \\
\hline
\end{tabular}

with an exception in capital market investments (of which Bank Mayapada records the lowest figures).

\section{Empirical Results}

\section{Production Frontier and Efficiency}

Table 2 reports the efficiency change of the 21 banks during the period of 2002-2004 under both constant returns to scale (CRS) and variable returns to scale (VRS). Values of unity imply that the firm is on the industry frontier in the associated year. Values less than unity imply that the firm is below the frontier or technically inefficient. Hence, the lower the values from unity the more inefficient it is compared to the values closer to one. For the years reported in Table 2, Bank Pan Indonesia, Bank Century Indonesia, Bank Permata, Bank Niaga, Bank NISP, Bank Muamalat Indonesia and Bank Bumiputera Indonesia are consistently efficient, both under CRS and VRS. In addition, Bank Danamon, Bank Syariah Mandiri, and Bank Ganesha are also found consistently efficient under VRS. On the contrary, Bank LIPPO, Bank Buana Indonesia, Bank Artha Graha International, and Bank Ekonomi Raharja are the least efficient banks for CRS and VRS versions, respectively. None of these banks is able to increase its distance to the industrial production frontier for both CRS and VRS.

The inverse of the values in Table 2 show the percentage of realized output level compared to maximum potential output level at the given input mix. For instance, Bank Syariah Mandiri and Bank LIPPO produced 87.2 percent and 40.2 percent of their potential outputs in 2004 under CRS, respectively. On the contrary, under VRS, Bank Syariah Mandiri and Bank LIPPO produced 100 percent and 65 percent of their potential outputs in the same year. As shown by the weighted 
Gadjah Mada International Journal of Business, January - April 2007, Vol. 9, No. 1

Table 2. Efficiency under CRS and VRS

\begin{tabular}{|c|c|c|c|c|c|c|}
\hline \multirow[t]{2}{*}{ Bank } & \multicolumn{3}{|c|}{ CRS } & \multicolumn{3}{|c|}{ VRS } \\
\hline & 2002 & 2003 & 2004 & 2002 & 2003 & 2004 \\
\hline Danamon Indonesia & 1.000 & 1.000 & 0.813 & 1.000 & 1.000 & 1.000 \\
\hline Internasional Indonesia & 0.765 & 1.000 & 0.329 & 1.000 & 1.000 & 0.414 \\
\hline Pan Indonesia & 1.000 & 1.000 & 1.000 & 1.000 & 1.000 & 1.000 \\
\hline Century & 1.000 & 1.000 & 1.000 & 1.000 & 1.000 & 1.000 \\
\hline Central Asia & 1.000 & 0.505 & 1.000 & 1.000 & 0.869 & 1.000 \\
\hline Permata & 1.000 & 1.000 & 1.000 & 1.000 & 1.000 & 1.000 \\
\hline Buana Indonesia & 1.000 & 0.183 & 0.330 & 1.000 & 0.201 & 1.000 \\
\hline LIPPO & 0.661 & 0.201 & 0.402 & 0.667 & 1.000 & 0.650 \\
\hline Niaga & 1.000 & 1.000 & 1.000 & 1.000 & 1.000 & 1.000 \\
\hline Bukopin & 1.000 & 1.000 & 0.112 & 1.000 & 1.000 & 0.119 \\
\hline NISP & 1.000 & 1.000 & 1.000 & 1.000 & 1.000 & 1.000 \\
\hline Mega & 0.681 & 1.000 & 0.633 & 0.706 & 1.000 & 1.000 \\
\hline Syariah Mandiri & 1.000 & 1.000 & 0.872 & 1.000 & 1.000 & 1.000 \\
\hline Ganesha & 0.946 & 1.000 & 1.000 & 1.000 & 1.000 & 1.000 \\
\hline Artha Graha Internasional & 0.389 & 0.204 & 0.046 & 0.394 & 0.899 & 0.112 \\
\hline Mayapada International & 1.000 & 0.502 & 0.555 & 1.000 & 0.714 & 1.000 \\
\hline IFI & 1.000 & 0.782 & 0.799 & 1.000 & 1.000 & 0.806 \\
\hline Muamalat Indonesia & 1.000 & 1.000 & 1.000 & 1.000 & 1.000 & 1.000 \\
\hline Bumiputera Indonesia & 1.000 & 1.000 & 1.000 & 1.000 & 1.000 & 1.000 \\
\hline Ekonomi Raharja & 0.270 & 0.070 & 1.000 & 0.377 & 1.000 & 1.000 \\
\hline Mestika Dharma & 1.000 & 0.180 & 1.000 & 1.000 & 0.338 & 1.000 \\
\hline Mean & 0.891 & 0.744 & 0.757 & 0.912 & 0.906 & 0.862 \\
\hline
\end{tabular}

geometric mean of Table 2, the average efficiency for the whole industry decreased significantly from 2002 to 2004 based on either CRS or VRS. The average efficiency performance of the national private banks is relatively higher based on VRS than CRS. Most of the banks achieved the highest efficiency in 2002, whilst the lowest efficiency was realized in 2004 for both VRS and CRS.

\section{Productivity Performance of Individual Banks}

Table 3 reports the performance of national private banks in adjacent periods from 2002 to 2004 for TFP change and its two subcomponents, technical change, and efficiency change. Additionally, the subcomponents of efficiency change are: (1) pure efficiency and (2) scale efficiency. Note 
Omar etal.-Efficiency and Productivity Performance of the NationalPrivate Banks...

that a value of the Malmquist TFP productivity index and its components less than one implies a decrease or deterioration. Conversely, values greater than one indicate improvements in the relevant aspect. Subtracting 1 from the number reported in the table provides us with information on average increase or decrease per annum for the relevant time period and relevance performance measure. It should also be noted that these measures capture performance relative to the best practice in the relevant performance or relative to the best practice in the sample.

Predicated upon the Malmquistbased TFP index, Bank Ekonomi Raharja, Bank Bumiputera Indonesia, and Bank Permata showed positive productivity changes for the two adjacent years within the study period. In contrast, Bank IFI and Bank Artha Graha recorded the highest deterioration in TFP for the year 2002-2004. In addition, Bank Mestika Dharma had the highest average TFP growth at an annual average rate of 998.1 percent, followed by Bank Ekonomi Raharja and Bank Century with annual rates of 546.5 percent and 344.7 percent, respectively. Overall, all the operators had increased their TFPs on average by at least 114 percent annually for the period of 2002-2004.

The Malmquist TFP index is further decomposed into its two components, technical change and efficiency change, which is reported in Table 3. Table 3 also presents the index values of technical progress/regress as mea- sured by average shifts in the bestpractice frontier from period $t$ to $t+1$. Bank Bumiputera Indonesia, Bank Mestika Dharma, Bank Permata, and Bank International Indonesia are found to experience technical progress from year 2002 to 2004 whilst the other banks experienced both technical progress and regress in the same period. Over the study period, Bank IFI recorded the highest change in technical regress (90 percent) in the year 2002-2003. However, in theyear 20032004, Bank IFI recorded the highest change in technical progress (4.8 percent). Table 3 also depicts technical progress experienced by 11 banks for the periods of 2002-2003 and 20032004. On average, the year 2002-2003 is found to be the year of technical regress (11.2 percent) whereas from the year 2003-2004 onwards, the Indonesian national private banks recorded technical progress (53 percent)

For the efficiency changes, the results indicate considerable variation across banks and time. Only seven banks are found to be efficient (and therefore showed no change in efficiency) in all periods from 2002 to 2004. For the other banks, there were periods with positive, negative or no changes in efficiency. Furthermore, the results show that many banks improved their efficiency during the period of 2003-2004. During the entire period of the study, the results show that, on average, Bank Ekonomi Raharja achieved the highest efficiency change by 824.3 percent. 
Gadjah Mada International Journal of Business, January - April 2007, Vol. 9, No. 1

Table 3. TFP Change and Its Components

\begin{tabular}{|c|c|c|c|c|c|c|c|c|c|c|}
\hline \multirow[t]{2}{*}{ Bank } & \multicolumn{2}{|c|}{ tfpch } & \multicolumn{2}{|c|}{ techch } & \multicolumn{2}{|c|}{ effch } & \multicolumn{2}{|c|}{ pech } & \multicolumn{2}{|c|}{ sech } \\
\hline & $02-03$ & 03-04 & $02-03$ & 03-04 & $02-03$ & 03-04 & $02-03$ & 03-04 & $02-03$ & 03-04 \\
\hline Danamon Indonesia & 1.015 & 0.458 & 1.015 & 0.564 & 1.000 & 0.813 & 1.000 & $\overline{1.000}$ & 1.000 & 0.813 \\
\hline Internasional Indonesia & 2.377 & 0.533 & 1.817 & 1.621 & 1.308 & 0.329 & 1.000 & 0.414 & 1.308 & 0.795 \\
\hline PanIndonesia & 1.751 & 0.404 & 1.751 & 0.404 & 1.000 & 1.000 & 1.000 & 1.000 & 1.000 & 1.000 \\
\hline Century & 0.476 & 8.418 & 0.476 & 8.418 & 1.000 & 1.000 & 1.000 & 1.000 & 1.000 & 1.000 \\
\hline Central Asia & 0.403 & 1.595 & 0.799 & 0.805 & 0.505 & 1.980 & 0.869 & 1.150 & 0.581 & 1.721 \\
\hline Permata & 1.258 & 3.707 & 1.258 & 3.707 & 1.000 & 1.000 & 1.000 & 1.000 & 1.000 & 1.000 \\
\hline BuanaIndonesia & 0.207 & 1.399 & 1.135 & 0.774 & 0.183 & 1.808 & 0.201 & 4.970 & 0.908 & 0.364 \\
\hline LIPPO & 0.643 & 1.088 & 2.121 & 0.542 & 0.303 & 2.006 & 1.500 & 0.650 & 0.202 & 3.084 \\
\hline Niaga & 0.683 & 1.702 & 0.683 & 1.702 & 1.000 & 1.000 & 1.000 & 1.000 & 1.000 & 1.000 \\
\hline Bukopin & 1.493 & 0.109 & 1.493 & 0.978 & 1.000 & 0.112 & 1.000 & 0.119 & 1.000 & 0.942 \\
\hline NISP & 0.886 & 0.882 & 0.886 & 0.882 & 1.000 & 1.000 & 1.000 & 1.000 & 1.000 & 1.000 \\
\hline Mega & 1.049 & 0.527 & 0.715 & 0.832 & 1.467 & 0.633 & 1.416 & 1.000 & 1.036 & 0.633 \\
\hline SyariahMandiri & 0.537 & 3.126 & 0.537 & 3.584 & 1.000 & 0.872 & 1.000 & 1.000 & 1.000 & 0.872 \\
\hline Ganesha & 0.963 & 2.131 & 0.911 & 2.131 & 1.057 & 1.000 & 1.000 & 1.000 & 1.057 & 1.000 \\
\hline Artha GrahaInternasional & 1.031 & 0.185 & 1.971 & 0.826 & 0.523 & 0.224 & 2.283 & 0.125 & 0.229 & 1.797 \\
\hline MayapadaInternational & 0.227 & 2.989 & 0.452 & 2.706 & 0.502 & 1.104 & 0.714 & 1.400 & 0.703 & 0.789 \\
\hline IFI & 0.078 & 1.071 & 0.100 & 1.048 & 0.782 & 1.022 & 1.000 & 0.806 & 0.782 & 1.268 \\
\hline MuamalatIndonesia & 0.822 & 4.715 & 0.822 & 4.715 & 1.000 & 1.000 & 1.000 & 1.000 & 1.000 & 1.000 \\
\hline Bumiputera Indonesia & 1.297 & 5.772 & 1.297 & 5.772 & 1.000 & 1.000 & 1.000 & 1.000 & 1.000 & 1.000 \\
\hline Ekonomi Raharja & 1.023 & 11.906 & 3.930 & 0.837 & 0.260 & 14.226 & 2.650 & 1.000 & 0.098 & 14.226 \\
\hline MestikaDharma & 0.282 & 21.679 & 1.567 & 3.903 & 0.180 & 5.555 & 0.338 & 2.957 & 0.532 & 1.878 \\
\hline Mean & 0.687 & 1.594 & 0.982 & 1.530 & 0.699 & 1.042 & 0.971 & 0.884 & 0.720 & 1.178 \\
\hline
\end{tabular}

Note $:$ tfpch = Total Factor Productivity change; effch = efficiency change; techch = technical change; pech $=$ pure efficiency change, and sech $=$ scale efficiency change 
Omar etal.-Efficiency and Productivity Performance of the NationalPrivate Banks...

In order to identify changes in scale efficiency, efficiency change is further decomposed into pure efficiency and scale efficiency changes. The results show that the scale efficiency appears to be a less important source of growth to efficiency change vis-à-vis the pure efficiency change component for the period of 20022003. In contrast, the scale efficiency appears to be more important than pure efficiency in 2003-2004. Seven banks recorded no changes in annual growth of both the scale and the pure efficiency during the period of 2000-2004. Compared to the other banks, Bank Buana had the highest deterioration of scale efficiency by 79.1 percent in 2002-2003. In terms of pure efficiency, Bank LIPPO showed the highest deterioration by 79.2 percent in 2001-2002. Surprisingly, Bank Buana is found to have the highest growth in pure efficiency by 397 percent in 2003-3004. On the other hand, Bank Ekonomi Raharja recorded the highest growth in scale efficiency by more than 13 times compared to its growth in the previous year.

Our findings imply that the size of the banks seems to be a less important determinant of the banks' productivity performance. A bigger bank is not necessarily more efficient than a smaller bank, and vice versa. This indicates that size does not matter in determining the banks' productivity performance. However, the size is not detrimental to a bank to improve its productivity performance. The pureefficiency is found to be a more important source of growth in efficiency changes. In order to improve their productivity performance, the national private banks have to emphasize how to further improve their pure efficiency such as how to optimally use the combination of inputs to produce a greater output efficiently.

\section{Productivity Performance of the Entire Industry}

Table 4 summarizes the performance of Malmquist productivity index of the national private banks in Indonesia from 2002 to 2004 . On average, Bank Ekonomi Raharja recorded the highest growth in TFP with 249 percent, efficiency and technical changes with 92.4 and 82.4 percent, respectively. Bank IFI, on the other hand, is identified as the lowest growth in TFP with -77.1 percent. On average, the improvement of TFP of the national private banks in Indonesia is mainly due to technical change (22.6 percent), whilst efficiency change contributes a negative change (14.6 percent) to the overall TFP growth (4.6 percent). Most of the banks experienced technical progress.

Furthermore, the efficiency change is found to be largely contributed by pure efficiency ( -7.3 percent) rather than by scale efficiency (-7.9 percent). This indicates that the size of the banks has no effect on efficiency changes. This finding is in harmony with the study of Asian Banker Research (2003), finding that bigger banks do not necessarily perform better in terms of productivity. Our findings of 
Gadjah Mada International Journal of Business, January - April 2007, Vol. 9, No. 1

substantial growth in efficiency components and negative growth in technical change suggest that the increase of TFP in the national private banks in Indonesia arises from the innovation in technology rather than from the efficiency components.

Our policy implication is that the national private banks in Indonesia have a greater potential to further improve their productivity and efficiency performance through an improvement in technical aspect of banking systems. Given the remarkable technological innovation within the banking industry worldwide, banking labor forces should be well trained and well equipped with state-of-the-art knowl-

Table 4. Summary of Malmquist Productivity Index of Bank Means, 20002004

\begin{tabular}{|c|c|c|c|c|c|}
\hline Bank & tfpch & effch & techch & pech & sech \\
\hline Danamon Indonesia & 0.682 & 0.901 & 0.756 & 1.000 & 0.901 \\
\hline Internasional Indonesia & 1.126 & 0.656 & 1.717 & 0.643 & 1.020 \\
\hline Pan Indonesia & 0.841 & 1.000 & 0.841 & 1.000 & 1.000 \\
\hline Century & 2.001 & 1.000 & 2.001 & 1.000 & 1.000 \\
\hline Central Asia & 0.802 & 1.000 & 0.802 & 1.000 & 1.000 \\
\hline Permata & 2.160 & 1.000 & 2.160 & 1.000 & 1.000 \\
\hline Buana Indonesia & 0.539 & 0.575 & 0.937 & 1.000 & 0.575 \\
\hline LIPPO & 0.836 & 0.780 & 1.072 & 0.988 & 0.790 \\
\hline Niaga & 1.078 & 1.000 & 1.078 & 1.000 & 1.000 \\
\hline Bukopin & 0.404 & 0.335 & 1.208 & 0.345 & 0.971 \\
\hline NISP & 0.884 & 1.000 & 0.884 & 1.000 & 1.000 \\
\hline Mega & 0.744 & 0.964 & 0.771 & 1.190 & 0.810 \\
\hline Syariah Mandiri & 1.296 & 0.934 & 1.388 & 1.000 & 0.934 \\
\hline Ganesha & 1.432 & 1.028 & 1.393 & 1.000 & 1.028 \\
\hline Artha Graha Internasional & 0.437 & 0.342 & 1.276 & 0.533 & 0.642 \\
\hline Mayapada International & 0.824 & 0.745 & 1.107 & 1.000 & 0.745 \\
\hline IFI & 0.289 & 0.894 & 0.323 & 0.898 & 0.996 \\
\hline Muamalat Indonesia & 1.969 & 1.000 & 1.969 & 1.000 & 1.000 \\
\hline Bumiputera Indonesia & 2.736 & 1.000 & 2.736 & 1.000 & 1.000 \\
\hline Ekonomi Raharja & 3.490 & 1.924 & 1.814 & 1.628 & 1.182 \\
\hline Mestika Dharma & 2.473 & 1.000 & 2.473 & 1.000 & 1.000 \\
\hline Mean & 1.046 & 0.854 & 1.226 & 0.927 & 0.921 \\
\hline
\end{tabular}

Note $:$ tfpch $=$ Total Factor Productivity change; effch = efficiency change; techch $=$ technical change; pech = pure efficiency change, and sech = scale efficiency change

$\overline{14}$ 
Omar etal.-Efficiency and Productivity Performance of the NationalPrivate Banks...

edge for optimizing technology so as to give the bank long-term competitive advantage. Information and communications technology (ICT) is one of the latest technology advancements that should be fully imbued into the banking systems so that the bank can compete with other banks in the era of ecommerce.

Hence, one area that needs a particular emphasis is technological knowledge dispersion. Training and technical expertise should beconstantly upgraded along with technological evolution. This can take the form of education and training programs intended to improve managerial ability, or of extension programs designed to speed up the adoption of new technologies.

\section{Conclusion}

The results found by this study have important implications for the national private banks in Indonesia in order to improve their efficiency and productivity performance. As for the whole industry, TFP has increased by 4.6 percent throughout the period of 2002-2004; with the year 2003-2004 recorded the highest growth (59.4 percent). Indeed, this particular period also recorded the highest technical and efficiency changes at rates of 53 percent and 42 percent, respectively. Nevertheless, it should be noted that the very presence of TFP growth in the national private banks has been mainly due to the technical change (22.6 percent) compared to the efficiency com- ponents (-14.6 percent). This finding accordingly indicates that the Indonesian national private banks have a great potential to further increase their TFP through an improvement in efficiency components.

Comparing two Islamic banks (Bank Syariah Mandiri and Bank Muamalat) to the other conventional commercial banks, we find that, on average, the two Islamic banks are more efficient than the other commercial banks. Bank Muamalat has recorded a positive growth in efficiency change whilst Bank Syariah Mandiri has recorded a negative efficiency change. Improving bank scale, technical efficiency, and efficiency change are the best way not only for the conventional private banks but also for the Islamic banks to gain a better position and competitive advantage over the other banks.

In addition, the efficiency change is largely contributed by the pure efficiency (-7.3 percent) rather than by the scale efficiency (-7.9 percent). This indicates that the size of the banks does not matter in determining productivity performance of the national private banks in Indonesia. For bigger-sized banks, it seems pivotal to reduce their size in order to improve efficiency. Eventually, as an addition to the findings of this study, further research needs to be directed towards policy formulation as well as its implications in order for the commercial banking industry to gain a better position with higher TFP growth. 
Gadjah Mada International Journal of Business, January - April 2007, Vol. 9, No. 1

\section{References}

Abd. Karim, M. Z. 2001. Comparative bank efficiency across ASEAN countries. ASEAN Economic Bulletin 18 (3): 289-304.

Afriat, S. N. 1972. Efficiency estimation of production functions. International Economic Review 13 (3): 568-598.

Alam, I., and R. Sickless. 1995. Long run properties of technical efficiency in the U.S. airline industry. Mimeo. Rice University.

Ali, A. I., and L. M. Seiford. 1993. The mathematical programming to efficiency analysis. In H. O. Fried, C.A.K. Lovell, and S. S. Schmidt (eds). The Measurement of Productive Efficiency: Techniques and Applications. New York: Oxford University Press: 120-159.

Amir, A. 2004. Level efficiency of Bank Islam Malaysia Berhad: A stochastic approach. Proceedings of the Malaysian Finance Association $6^{\text {th }}$ Annual Symposium, 5-6 May. Langkawi: 743-753.

Asai, S., and J. Nemoto. 1999. Measurement of efficiency and productivity in regional telecommunications business. Institute for Post and Telecommunications Policy Discussion Paper 3 (June 25).

Asian Banker Research. 2003. Bigger is not necessarily better: Bank Central Asia outshines bigger players (October).

Avkiran, N. 2001. Investigating technical and scale efficiencies of Australian universities trough Data envelopment analysis. Socio-Economic Planning Sciences 35: 57-80.

Beccalli, E. 2004. Cross-country comparisons of efficiency: Evidence from the UK and Italian investment firms. Journal of Banking \& Finance 28: 1363-1383.

Berger, A. N., Hunter, W. C., and S. G. Timme. 1993. The efficiency of financial institutions: A review and preview of research past, present and future. Journal of Banking and Finance 17 (2 and 3): 221-250.

Berger, A. N., and D. B. Humphrey. 1997. Efficiency of financial institutions: International survey and direction for future research. European Journal of Operational Research 98: 175-212.

Calabrese, A., D. Campisi, and M. Paolo. 2001. Productivity change in the telecommunications industries of 13 OECD countries. International Journal of Business and Economics 1 (33): 209-223.

Carvallo, O., and A. Kasman. 2005. Cost efficiency in the Latin American and Caribbean banking systems. Journal of International Financial Markets, Institutions and Money 15: 55-72.

Charnes, A., W. W. Cooper, and E. Rhodes. 1978, Measuring the efficiency of decision making units. European Journal of Operational Research 2: 429-444.

Coelli, T. 1996. A guide to DEAP version 2.1 data envelopment analysis (computer) program. CEPA Working Paper 96/98. Armidale: University of New England, CEPA. 
Omar etal.-Efficiency and Productivity Performance of the NationalPrivate Banks...

Cummins, J. D., S. Tennyson, and M. A. Weiss. 1999. Consolidation and efficiency in the US life insurance industry. Journal of Banking and Finance 23: 325-357.

DeYoung, R., and I. Hassan. 1998. The performance of Novo Commercial Banks: A profit efficiency approach. Journal of Banking and Finance 22: 565-587.

Diacon, S. R., K. Starkey, and C. O'Brien. 2002. Size and efficiency in European longterm insurance companies: an international comparison. The Geneva Papers on Risk and Insurance 27 (3): 444-466.

Fare, R., G. Shawna, L. Bjorn, and P. Ross. 1989. Productivity development in Swedish hospitals: A Malmquist output index approach. Mimeo.

Fare, R., G. Shawna, N. Mary, and Z. Zhongyang. 1994a. Productivity growth, technical progress and efficiency change in industrialized countries. American Economic Review 84: 66-83.

Fare, R., G. Shawna, and L. Knox. 1994b. Production Frontiers. New York: Cambridge University Press.

Fries, S., and A. Taci. 2005. Cost efficiency of banks in transition: Evidence from 289 banks in 15 post-communist countries. Journal of Banking and Finance 29: 55-81.

Forsund, F. 1991. The Malmquist productivity index. Paper presented at the $2^{\text {nd }}$ European Workshop on Efficiency and Productivity Measurement. Berlgium: Centre of Operations Research and Econometrics, University Catholique de Louvain, Lauvain-la-Neuve.

Hassan, M. K., and D. R. Tufte. 2001. The x-efficiency of a group-based lending institution: the case of Grameen bank. World Development 29 (6): 1071-1082.

Kwan, S. H. 2003. Operating performance of banks among Asian economies: An international time series comparison. Journal of Banking and Finance 27:447-489.

Mao, W., and W. Koo. 1996. Productivity growth, technology progress and efficiency change in Chinese agricultural production from 1984 to 1993. Agricultural Economics Report 362. North Dakota Sate University.

Mukherjee, K., S. C. Ray, and S. M. Miller. 2001. Productivity growth in large US commercial banks: The initial post-deregulation experience. Journal of Banking and Finance 25: 913-939.

Pastor, J. M., F. Perez, and J. Quesada. 1997. Efficiency analysis in banking forms: An international comparison. European Journal of Operational Research 48: 231-249.

Sathye, M. 2002. Measuring productivity changes in Australian banking: An application of Malmquist indices. Managerial Finance 28: 48-59.

Sturm, J-E., and Williams. 2004. Foreign bank entry, deregulation and bank efficiency: Lessons from the Australian experience. Journal of Banking and Finance 30: 1-25.

Tauer, L. 1998. Productivity of New York dairy farms measured by non-parametric indices. Journal of Agricultural Economics 49 (2): 234-249.

Tulkens, H., and A. Malnero. 1996. Non-parametric approach to the assessment of the relative efficiency of bank branches. In David. M (eds), Sources of Productivity Growth. Cambridge: Cambridge University Press. 
Gadjah Mada International Journal of Business, January - April 2007, Vol. 9, No. 1

Wheelock, D. C., and P. W. Wilson. 1999. Technical progress, inefficiency and productivity change in U.S. banking, 1984-1993. Working Paper 1994-021B. Federal Reserve Bank of ST.Louis. 